\title{
Prevalence of Mycoplasma Gallisepticum (Mg) Antibodies in Guinea Fowls (Numida mileagris) and Pigeons (Columba livia domesticus) in Sokoto, Nigeria
}

Mera UM, Mudasir H, Abdulrahman L and Abdulmalik SB*

Department of Veterinary Medicine, Faculty of Veterinary Medicine, Usmanu Danfodiyo University, Sokoto

Department of Veterinary Microbiology, Faculty of Veterinary Medicine, Usmanu Danfodiyo University, Sokoto

\section{Article History \\ Received: 26.08.2020 \\ Accepted: 10.09 .2020 \\ Published: 12.10 .2020}

Journal homepage:

https://www.easpublisher.com/easjvms

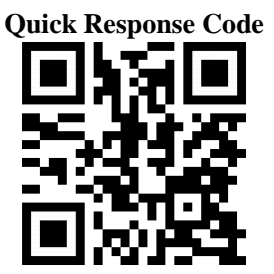

Abstract: A total of 200 sera samples were collected from Guinea fowl (100) and Pigeons (100) and subjected to Indirect Enzyme-Linked Immunosorbent Assay (ELISA). Out of these, 99 samples $(49.5 \%)$ were found positive for MG antibodies. The prevalence of MG infection was $60 \%$ in Guinea fowl and $39 \%$ in Pigeons. In Guinea fowls the males has a slightly high prevalence of $61.7 \%$ compared to the females with a prevalence rate of 57.5\%. This study revealed that Mycoplasma gallisepticum infection is prevalent and widespread in both Guinea fowls and Pigeons within Sokoto metropolis. In Nigeria and most part of Africa these two species are usually reared in the same households with the local chickens hence may serve as potential source of infection to them resulting in a more severe disease in the chicken population.

Keywords: Mycoplama, Mycoplasmosis, Guinea fowl, Pigeon, Avian, Sokoto, Nigeria.

Copyright (C) 2020 The Author(s): This is an open-access article distributed under the terms of the Creative Commons Attribution 4.0 International License (CC BY-NC 4.0) which permits unrestricted use, distribution, and reproduction in any medium for non-commercial use provided the original author and source are credited.

\section{INTRODUCTION}

Mycoplasmas are bacteria that lack cell wall and belong to the class mollicutes and family mycoplamataceae [1]. Organisms which have been thought to be avian mycoplasmas were first isolated from chickens in 1935. Subsequently, several serotypes later classified as species were cultured, mostly from chickens and turkeys. However, the distribution of mycoplasmas seems to be worldwide in avian species. Poultry specialists are mainly interested in avian mycoplasmas associated with diseases of domestic poultry. To date, sixteen species (Mycoplasma gallisepticum, M. synoviae, M. meleagridis, M. iowae, M. lipofaciens, M. gallopavonis, M. gallinaceum, $M$. gallinarum, M. iners, M. pullorum, M. cloacale, $M$. imitans, Acholeplasma laidlawii, A.equifetale and Ureaplasma gallorale) have been isolated from chickens. Infectious diseases such as avian mycoplasmosis are potential constraint to the health status and productivity of domestic chickens. Mycoplasmosis is one of the important disease problems of poultry in Nigeria, and it affects both commercial exotic breeds and indigenous breeds [2]. Avian mycoplsma infection causes decreased feed efficiency, poor carcass quality and sub-optimal egg production in layer chickens, turkeys and other avian species [3].

Mycoplasma gallisepticum, M. synoviae, M. meleagridis, and $M$. iowae are the four major pathogens that causes mycoplasmosis in poultry birds $[1,4]$. Among these species, M. gallisepticum is the most important cause of chronic respiratory disease in chickens [5]. Birds of all age groups are susceptible to this disease, but young birds are more prone to infection than adults [1]. M.gallisepticum infection causes decreased egg production in chickens, turkeys and other avian species.

Guinea fowl originates from the Guinea coast of Africa. However, they have a worldwide distribution with different management practices in different parts of the world. In Asia and Latin America, it is reared as semi-domesticated species while in Europe, North America and Australia large scale commercial production occurs. Despites the fact that it originates from Africa, in most part of the continent guinea fowl are reared at subsistence level. 
There are three species of guinea fowl as reported by, these are; helmeted guinea fowl (Numinidae maleagridis); they are the most common species of guinea fowl named for the bony helmet on their head, crested guinea fowl (Guttera pucherani) which originates from South Africa. They can be distinguished from other guinea fowl by their black head plumes and vulturine guinea fowl (Acrillium vulturinum) which originates from the semi-arid region of east Africa. It is more sensitive to cold and lacks the hardiness of the common guinea fowl. It has a helmetless head and resembles a vulture.

In most African countries guinea fowl are reared mainly under extensive (free range or traditional) and/or semi-intensive systems [6, 7]. Moreki [8] stated that the free range system is the predominant rearing method common in Africa.

Guinea fowl are a source of protein (eggs and meat) and income. Guinea fowl meat is high in protein and low in fat content, thus it is highly prized compared to chicken meat [8]. Guinea fowl meat has a protein content of about $28 \%$ compared to $20 \%$ for domestic fowl [9]. In addition to their main use as a source of income and protein, guinea fowl play important roles in the socio-cultural lives of many tribes [10]. Guinea fowl are resistant to most poultry diseases at the adult age [10] and require less labour and management than chickens [11].

The domestic pigeon (Columba livia domesticus) is sub specie of pigeon that was derived from the rock dove (rock pigeon) which is considered to be the world's oldest domesticated bird, research suggests that domestication of the pigeon occurs as early as 10,000 years ago [12].

Pigeons have made considerable consideration to humanity especially in times of war [13] where their homing ability was put to use by making them messengers (carrier pigeons). Pigeons are use as a source of meat popularly known as squab (from young birds), a breed of large white pigeons named 'King Pigeons' have also been developed by selective breeding for commercial meat production. Breeds of pigeons developed for their meat are collectively known as utility pigeons.

\section{Materials ANd Methods}

The study was conducted in Sokoto metropolis. The state of Sokoto in Nigeria is a semi-arid region located to the extreme North-western Nigeria between longitudes $4^{\circ} 8^{\prime} \mathrm{E}$ and latitudes $12^{\circ} \mathrm{N}$ and $13^{\circ} 58 \mathrm{~N}$ while the metropolis lies between latitude $13^{\circ} 3^{\prime}$ $490 \mathrm{~N}$, longitude $5^{\circ} 14^{\prime} 890 \mathrm{E}$ [14]. It shares boundaries with the republic of Niger to the North, Kebbi state to the west and south west and Zamfara state to the east. The state covers a total land area of about 28,232,370 square kilometres with population of $3,696,999$ while the metropolis has estimated population of 427,760 based on 2006 census [15]. The climate of the area is semi-arid characterized by cold dry and hot dry seasons that begins from October and extends up to April, warm wet (rainy) season commences from May and end in September with an annual average rainfall ranging between $400 \mathrm{~mm}-1300 \mathrm{~mm}$ [16]. The mean monthly temperature ranges from $13^{\circ} \mathrm{C}$ in December through February and $40^{\circ} \mathrm{C}-44^{\circ} \mathrm{C}$ in April and May. The relative humidity on the average is between $10 \%$ and $90 \%$. The state is rich in livestock resources with an estimated 3 million sheep, 5 million goats, 4,600 camels, 52,000 donkeys and remarkable number of local and exotic poultry species [17]. The main occupation of the people in the state is arable farming.

A total of 200 blood samples (100 Guinea Fowls, and 100 from Pigeons) were collected using plane sample bottles the main live birds market in Sokoto Metropolis and transported to the Usmanu Danfodiyo University, Sokoto Veterinary Chemical pathology laboratory for processing. The blood sample was kept at room temperature for 6 to 8 hours until the blood clots.

The serum was decanted in centrifuge tube and centrifuge at $2000 \mathrm{rpm}$ for 5 minutes to have a clear serum. The serum was then collected in another bottles and then transported to the Central laboratory for preservation at $-20^{\circ} \mathrm{C}$ until further processing for the serological study.

Indirect enzyme-linked immunosorbent assay (ELISA) was employed to detect antibodies against MG infection using ID.vet Innovative Diagnostics France MG ELISA Kit (Lot No. E85).

\section{RESUlTS}

From the two hundred (200) sera samples subjected to ELISA test, Ninety nine (99) sera samples were found to be positive, giving an overall prevalence of $49.5 \%$. Guinea fowl had a prevalence rate of $69 \%$ compared to the Pigeons with a prevalence rate of $39 \%$ (Table).

In Guinea fowls the males has a slightly high prevalence of $61.7 \%$ compared to the females with a prevalence rate of $57.5 \%$ (Table 2 ). 
Table-1: Prevalence of Mycoplasma Gallisepticum Antibodies in Guinea Fowls and Pigeons in Sokoto, Nigeria

\begin{tabular}{|l|c|c|c|}
\hline \multicolumn{1}{|c|}{ Specie } & Number Tested & Number of Positive & Prevalence rate (\%) \\
\hline Guinea fowl & 100 & 60 & 60 \\
\hline Pigeon & 100 & 39 & 39 \\
\hline Total & 200 & 99 & 49.5 \\
\hline
\end{tabular}

Table-2: Prevalence of Mycoplasma Gallisepticum Antibodies in Guinea Fowls based on sex In Sokoto, Nigeria

\begin{tabular}{|l|c|c|c|}
\hline \multicolumn{1}{|c|}{ Sex } & Number Tested & Number of Positive & Prevalence rate (\%) \\
\hline Male & 40 & 23 & 57.5 \\
\hline Female & 60 & 37 & 61.7 \\
\hline Total & 100 & 60 & 60.0 \\
\hline
\end{tabular}

\section{DISCUSSION}

This study found Mycoplasma galisepticum seroprevalence in Sokoto, Nigeria to be $60 \%$ in guinea fowls and $39 \%$ in pigeons. In guinea fowls the males has slightly higher prevalence of $61.7 \%$ compared to the females with $57.8 \%$. The prevalence of $60 \%$ found in guinea fowls is similar to that of a related study in chickens in Sokoto Nigeria [18] where an overall prevalence of $65.5 \%$ was found in chickens. In that same study the prevalence in local chicken was $57 \%$ compared to $72 \%$ in commercial chicken, within the commercial chicken, broilers has $56 \%$ while layers has $88 \%$ seroprevalence. The finding in guinea fowls was in close agreement with the study of Chrysostome et al. [19] in local chickens in Benin with a prevalence of $62 \%$. This high number was attributed to crossreactivates. In France, MG infection in egg samples was also high $(68 \%)$ probably due to selection of symptomatic cases of hens. In analogous study in Germany, the prevalence of mycoplasma infection in eggs of the bird (Accipiter gentilis) by using PCR technique was $0.7 \%$. However the low MG-DNA detection in the study was explained by the poor sample quality resulting in false negative results. The infection in other tissues, particularly the genital tract was low. The study of Talha [20] demonstrated that MG infections are not only widespread in commercial layer and broiler chickens but also in local (village, backyard) chickens. Similarly, the present study revealed that MG is prevalent in both guinea fowl and pigeon. The relatively lower prevalence $(39 \%)$ detected in pigeons may be attributed to the fact that they don't freely mix with the other avian species (chickens, turkeys, ducks and guinea fowls within the household or the backyards compared to the manner the others do.

\section{CONCLUSION}

Findings from this study revealed that Mycoplasma gallisepticum infection is present in guinea fowl and pigeon within Sokoto metropolis with prevalence of $60 \%$ and $39 \%$ respectively. There is the need for increased vigilance for early detection and biosecurity to prevent introduction and spread of the disease by poultry men.

\section{REFERENCES}

1. Bradbury, J. (2001). Poultry Diseases (Avian Mycoplasmosis). $5^{\text {th }}$ Edition, W. B. Saunders Company, Iowa, U.S.A. Pp178-193

2. Abdu, P. A. G., Bishu, A., Adysiyun, A. and Adegboye, D. S. (1993). Survey for Mycoplasma gallisepticum and Mycoplasma synoviae antibodies in chickens in Zaria, Nigeria. J. Anim. Prod. Res., 3, 63-69.

3. Hossain, K., Ali, M., \& Haque, M. (2007). Seroprevalence of Mycoplasma gallisepticum infectionin chicken in the greater Rajashahi district of Bangaladesh. Bangaladesh Journal of Veterinary Medicine 5:09-14

4. Evans, J. D., Leigh, S. A., Branton, S. I., Collier S. D., Pharr, G. T., \& Bearson, S. M. D. (2005): Mycoplasma gallisepticum: current and developing means to control avian pathogen. Journal of applied poultry research 14: 757-763.

5. Ley, D., \& Yoder, H. (1997). Mycoplasmosis/ Mycoplasma gallisepticum infection. Diseases of Poultry, 10th Edn. Ames: Iowa State Univ. Press, USA.

6. Dahouda, M., Toleba, S.S., Youssao, A.K.I., Kogui, S.B., Aboubakari, S.Y., \& Hornick, J.L. (2007). Guinea fowl rearing constraints and flock composition under traditional management in Borgu Department, Benin. Family Poultry, 17(1,2); 3-14.

7. Kusina, N.T., Saina, H., Kusina, J.F., \& Lebel, S. (2012). An insight into guinea fowl rearing practices and productivity by guinea fowl keepers in Zimbabwe. African Journal of Agricultural Research, 7(25):36213625.

8. Moreki, J.C., \& Seabo, D. (2012). Guinea fowl production in Botswana. Journal of World's Poultry Research, 2(1):01-04

9. Ayeni, J.S.O. (1980). The biology and utilization of the helmeted guinea fowl (N.m. galeata pallas) in Nigeria. Ph.D. Thesis, University of Ibadan, Nigeria.

10. Teye, G.A., \& Adam, M. (2000). Constraints to guinea fowl production in northern Ghana: A case study of the Damongo area. Ghana Journal of Agricultural Science 33:153-157. 
11. Sayila, A. (2009). Guinea fowl farming becomes popular in Botswana. World Poultry, 25(10): 3031.

12. Bleachman, A. (2007). Pigeons in the fascinating saga of the world's most revered and reviled bird. University of Queensland. St. Lucia Queensland.

13. Levi, W. (1977). The Pigeon. Levi Publishing Co. Inc. Sumter S.C.

14. MOI. (2008). Ministry of information, Sokoto, Nigeria. Diary, 12

15. NPC. (2006). Population Census Figures, National Population Commission, Abuja, Nigeria.

16. RIM. (2007). Nigerian Livestock Resources Inventory and management report. National synthesis, Section II(5): FDLPC, Abuja

17. Mamman, A. B. (2000). Sokoto State. In Udo, R, K, and Mamman A. B. (Eds.) Nigeria giant in the trophics. Gabuno Publishing Company, Lagos, 437-447

18. Mera, U. M., \& Mudasir, H. (2019). Prevalence of Mycoplasma galisepticum (MG) antibodies in chicken in Sokoto, Nigeria.EAS Journal of Veterinary Medical Services, 1(5), 58 - 59

19. Chrysostome, C. A. A. M., Bell, J. G., Demey, F., \& Verhulst, A. (1995). Seroprevalence to three diseases in village chickens in Benin. Prev. Vet. Med., 22, 257-261.

20. Talha, A. F. S. M. (2003). Investigation on the prevalence and significanceof $M$. Gallisepticum in village chicken and possibility of establishing $M$. Gallisepticum free flocks and significance of $M$. Gallisepticum in different production parameters on layer chicken in Bangaladesh. MSc Thesis. 